\title{
下顎骨，化骨トメッケル氏軟骨
}

\author{
大阪帝國大學醫學部解剖敎室(指導 富田教授) \\ 同蔺科敎室(指導号倉教授)
}

可 兒 一 郎

\section{Ein Beitrag zur Ossifikation des Unterkiefers.}

\section{Von}

Dr. Ichiro Kani.

Aus der Anatomischen Abteilung und der Zahnärztlichen Klinik der Kaiserlichen Universität zu Osaka: (Leiter Prof Dr. med H. Tomita (Anatom. Abt.) und Prof. Dr. med. S. Yumikura (Zahnärztl. Klinik.))

Der Verf. hat Unterkiefer menschlicher Foeten mit Xylol durchsichtig gemacht, ausserdem Serienschnitte sowie Wachsmodelle derselben hergestellt, um dadurch die Ossifikation des Unterkiefers zu untersuchen. Die erzielten Ergebnisse lassen sich folgendermassen zusammenfassen :

1) Die Ossifikation des Unterkiefers fängt schon in der 6.-7. Foetalwoche an.

2) Im Beginn der Verköcherung lassen sich 4 Ossifikationszentren auf der Aussenseite des Meckel'schen Knorpels und ausserdem noch 2 accesorische Knorpel nachweisen.

3) Die Resorption des Meckel'schen Knorpels beginnt zuerst im Bereiche des Foramen mentale, um sich von dort aus weiter zu verbreiten.

4) Gegen Ende des 3. Foetalmonats entstehen die Alveolen für die Milchzähne.

5) Die Verknöcherung der Unterkiefersymphyse erfolgt erst im postembryonalen Leben.

(Autoreferat.)

\section{(內 容 抄 錄)}

余ハ「キシロール」透明法ニョリ人胎兒下顎 部 檢索併セテ組織標本及ビ蠟模型 下顠骨ノ化骨卜メッケル氏軟骨卜，關係习調 查シ以下,所見 7 得タル ルモノデアル。

1.下顎骨，化骨八胎生1ヶ月牛二始マル。
2．化骨起始點ハメッケル氏軟骨外側結締 組糡中二四ツ補助軟骨二ツデアル。

3.メッケル氏軟骨八始メ攧孔部附近二於 テ侵蝕セラル。

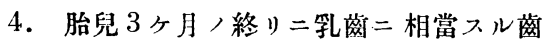
槽, 存在 $\exists$ 見ル。 
5. 下顎兩牛部八正中線二於テ結締織性連 ル。以上 結ヨ有スルモノデ分娩後化骨 ヨ見ルモノデア

目次

I 緒 言

II 研究材料

III 研究方法

IV 研究成績
$V$. 總 括

VI 結 論

VII 文 獻

VII 附 畗

\section{I. 緒 言}

由來顎学，研究八胎生學解剖學近二組織學的二更二進ンデハ生理學病理學的方面カ ラ盛ン二研究サレタノデァル就中下顎骨ノ䃝究ハ限局的二見易ク多大ノ興味アルモノ トサレテキル。回顧スレバ 18 世紀二 Hamphry 站二Sutton ニヨリ極ク簡易二解剖 學的觀察ガ行ハレソノ所見發表キ第シテキル, 又 Röse 二低り人類齒牙ノ發育二關聯 シ顎骨狀態ノ變化スル事二就キ報告テ見ル，更二又ソノ世紀未二當リテハToldt 出

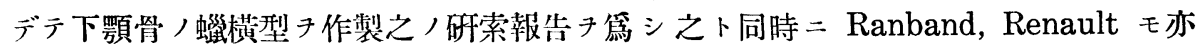
形態學的啝究キ遂ゲ各ソノ所見チ公ニシテッル。次デ 19 世紀二至リテ之ガ研究縊? 盛ントナリ主トシテ組織學的方面ノ觀察行ハレ Schenk, Heitzmann, Tomes Herpin, 等ノ研究報告續出 シ, 又一方 X線學的方面ヨリノ攻究モ盛ントナリ, WalKopf, Witzelkarl 近ク八我ガ國二於テ日本人齒牙發育機轉二關スル青木愽上ノ研究發表アリ。 顎咸所見モ併七記述七ラレテキル。劣組織解剖學的二口腔二關與スル諸藏器各部ノ正 不正狀態二就キ發生學的研究發表キ 1924 年 Fawcett ガ行ヒ大イ二貢獻スル處デアッ タ。

余ハ婴軟骨ノ「キシロール」ニ低ル透過度二興味チ持チ下顎骨ノ簡易檢索法トシテ之 チ應用シ胎生期ニアル日本人胎兒二試に併七テ同一切片チ使用シテ䗨板模型き作製前

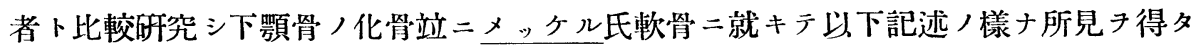
ノデ立二報告セントスルモノデアル。（兓二本報告ハ 1931 年 4 月東京二於ケル口腔病 學會二於テ發表シタ。)

\section{II. 研究材料}

余八研究目的八下顎骨，化骨狀況 7 檢索入 ルヨ以テ主眼トシタ,デ胎生期ニアル人胎兒 ヨ必要卜スルモノデアル從ッテ，ソノ材料蒐 集八非常二至難トル所デアツタガ，幸二大阪 帝國大學醫學部解剖敎室カラ所要, 人胎兒下 顎骨 ヨ供與サル、，好意二接シ 40 數例二就
キ检索ヨ行ヒ得タノデアル。而モ胎生初期力 ラ順次追究 $\exists$ 爲 得タ。ソノ材料ノ多ク 八手 術的ニ得タルモノデ胎兒身長測定至難ナルヨ 以テ最終月經力ラ處置日迄, 日數习起算シ檢 索ヨ行フ事トシタ。 


\section{III. 研究方法}

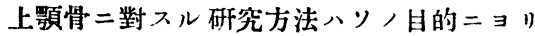
異ナルモノデアル, 即手肉眼的檢查, 組織顯 微鏡的檢索竝ニ「レントゲン」線寫真二依ル探 究更ニ進ンデ八蠟板模型ニ依ル研究或八組織 透明法隹用二依ル檢查等デアル。

余ノ使用七シ力法八「キシロール」透明法テ アッテ之ヨ基礎トシテ，更二進ンデ同標本 用ヒソ八組織學的連續切片 $フ$ 作製ハンゼン氏 门へトキシリン，エオジン」染色標本 $\exists$ 作り 之二依ル螠板模型 $\exists$ 作製シ比較研究シ以テ目 的達成二努力シタ。「キシロール」依ル透明 方法八最モ簡易二且ッ明磪デアッテ而モ肉眼 的檢索可能デ容易ニソノ立體的關係 $\exists$ 攻究シ 得ルノデアル。タ・至難ナル八組織片が柔軟 ナルヨ以テ下顎骨 $\exists$ 胎兒口腔中 $ョ$ 分離剔出 スル場合相當困難ヨ伴フモノデアル。

先ッ゙「フォルマリン」液中貯藏,人胎兒カラ

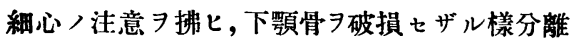
ス。但 シ胎生 $1,2,3$ ケ月二於テ八剝離困難ナ ルが故ニ之ヨ行ハズ次デ上行性「アルュール」
法二依リ脫水シ，無水「アルコール」习通ジキ シロール」液中二投入シタ。此，際起ル透明度 ヨ隹用シテ各々石灰化, 狀態 アル。

觀察法トシテ八援大鏡 $习$ 用七或八透過光線 ニョル局部觀察ヨ行フタ調查後ハ再ビ「アル コール」溶液中二㞍シテ保存シタ。之ヨ約言ス ルト次ノ栐デアル。

1.「フォルマリン」液固定 (10\%) 3 週間以 上(胎兒, マ、)

2. 水洗牛日 (所要部 7 分離剔出)

3.「アルコール」脫水

$$
\begin{aligned}
& 50 \% \text { アルコール! } 1 \text { 日 }
\end{aligned}
$$

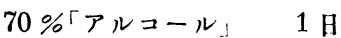

$$
\begin{aligned}
& 90 \% 「 ア ル ュ ー ル 」 \quad \text { 牛日 } \\
& \text { 無水「アルコール」 } 1 \text { 日 }
\end{aligned}
$$

4.「キシロール」透明

$$
\text { 第一液 } 2 \text { 時間 第二液 } 2 \mathrm{H}
$$

5. 調 查

\section{IV. 研究成績}

胎兒各月二於々ル下顎骨調查狀況

1, 胎生一ケ月 此ノ期二於ケル下颚部ハ唾 單ニメッヶル氏軟骨 ヨ圭體ト七ル袋狀樣軟唯 織塊卜モ見ル可キモノデソノ他部卜ノ聯絡區 别ノ如キモノ八全ク制然セナ1。此入際化骨 點习認メナカッタ。タ、橫断面二於テメック ル氏軟骨 $\exists$ 中心卜スル彈性二富么軟骨細胞二 分化ス可キ細胞群集，稍了榅圆形二近キ集團 $\exists$ 作り中央二位シ周圍 7 纖維樣結締織細胞デ 組被覆サレテ居ルノヨ認入タ。蒛胚, 發現 認メ十 1 。

口, 胎生 2 ケ月 胎生 1 ケ月牛 7 過ギル頃

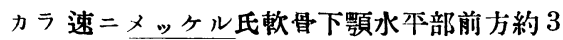
分， 1 邊二當リソ，外方二著明ナル內外二ッ ，化骨部 习認メル本化骨八上方八哆開シ下外 少ニ於テ合スルモノデアッテ，ソノ橫斷面デ
八 $\mathrm{V}$ 字型形態ヨナシソ, 兩脚, 合流點八下外 方ニアルヨ認メル，ソ八骨梁周圍二於テ八著 明ナル化骨細胞ノ活動セルヨ認ムルコトが出 來ル。本V字型站ニメッケル氏軟骨，關係、 余ノ作レル「パラフイン小模型ニ於テ明カ二認 メル事が出來ル。

䏌骨 $\mathrm{V}$ 字型開口部二於テ口腔內粘膜 $コ$ 來

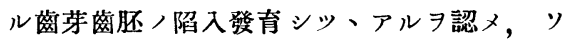
ノ內部二於テハ血管神經, 通過セルヨ證明シ 得タ。師チ此ノ場所八後來蒛槽骨タル可キ所 デアル。而シテ齒槽外板, 化骨內八板ョりモ 早ク且ッ著大デアル。又メッケル氏軟骨二近 キ内板外側郎手本軟骨卜，間二八瀻維樣結締 組織ニ富メルフ認メタ。

正中部橫断面二於テハメッケル氏軟骨，外 
側二後來下罘骨トナル可キ骨梁, 發育习認又

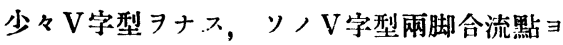
リナル骨梁ノ發育八此ノ際最モ著明デメッケ ル氏軟骨 $コ$ 遠クョリ內方二包ンデ居ル樣ナ觀 ガアル。

此ノV字型部二八又苜帶ノ入ッテ居ルノ 認又ル。此 八時期二於テ此, 部骨梁八既 $=3$ 分ノ 1 /部ョリノ骨卜共二癒合スルノヨ認メル。

後方 3 分, 1 八多少「キシロール」透明標本 二於テ暗影ヨナシテ居ル。ソノ末端二當ル場 所八稍?著明デアル。左右下效各牛, 相接入 ル所八纖維樣結締組織ノミョリ成ツテ居ル。 佾頣孔八上方開放七ル溝狀トシテ現ル。此， 時期二舌發生习認メル。

八, 胎生 3 ケ月 此>時期二於テ中央 3 分 , 1 八後方 3 分, 1.ョリ來ル化骨部卜相連ル モノデアッテ初メV字型骨梁外板, 連絡 7 來 シ次デ內板ノ接續スルラ見ルモノデアル。

前方 3 分, 1 八䠶二胎生 2 ケ月末期二於ヶ ル狀態ト一致スルラ以テ此處二略ス。頷孔八 既二完全ナル骨質ニョリ圍繞セラレタル孔卜 シテ存在入。

後方 3 分 1 メメッヶル氏軟骨外方二牛圆 形ヨナシ發育スルモノデアッテ之ヨ上下二ッ 八部分二區別スル事が出來ル。仔細二觀察ス ルト上下二ッノ化骨點 7 認メルコトが出來 ル。此八二點八本期二於テ可ナリ著明二發育 スルモノデアル。更二上外方二於テ前者卜 稍了遲レテ化骨ノョリ少キ狀態ニアル場所 7 見出シ得ルモノデアル。

師千是等ノモノ八約言スレバ上最弱化骨, 中；下强化骨 7 來七ルモノト區別スルコトが 出來ル而シテ前者八後來烏啄突起二中央 $モ$ 八 八所謂グレ一氏/補助軟骨 $\exists$ 有シ後來顆狀
突起 ヨ形成スル所デアル，共二軟骨化骨デア ル。

最下ノモノ八下顎隅角下緣部 ヨ形成スルモ ハデアル。是等ノ三ッハ各々前方二走り宜二 癒合スルモノデアル。メッケル氏軟骨ハ一側 下顎前牛部二於テハV字型內板軟骨側二骨梁 ，發青 ヨ來シ遂ニ之二面スル軟骨部 $ョ$ リソ, 侵蝕ヨ招來スルヨ認么。蒛牙八發育行程八漸 次進步 シ既二珐瑯器, 齔乳頭 7 區別 シ, 更二 齒囊ニョリ包括サレルヨ認メタ。而シ未ダ齒 芽, 石灰化八證明スル事が出來ナカッタ。

二, 胎生 4 ケ月 此，期二達スレバ既 $=6$ ケ所ョリスル各化骨行程八互二連續シ一大骨

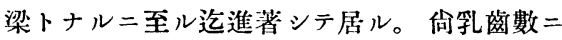
相當スル蒛槽, 發育現ル。タ・シ正中二於テ 八份依然トシテ纖維樣被膜,ミ連接サレテ居 ル。メッヶル氏軟骨，侵触被害八更二著シク 恰モ月ノ缺ケ行ク樣二壓排消失シッ、アルフ見 ル。最後方部二於テ八佾舊體ヨ維持シテ居ル。

木, 胎生 5 ケ月 此八期二於テ 八化骨八各 々ソ八起始部二於テ最モ著明ニシテソレヨ離 ル、ト共ニ粗ナルヨ認ム。下顎中央部二於テ

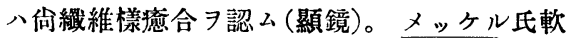
骨外八上方ョリ侵蝕著シク三日月狀二侵蝕サ レルヨ見ル(中央部 3 分，1），蒛芽發育顯著 ニシテ既二齒槽內二於テハ透明標本ニョほソ ，基底ヨリ放線狀二分布サレル血管，馳驅又 ルヨ見ル。

へ, 胎生 6 ケ月 胎生 4 ケ月頃二後來頣孔 トナル皆所，化骨卜共ニソ，部內側ニアッテ 吸收ノ始マッタメッタル氏軟骨入漸次前後二 侵強サレテ此ノ期ニ及ンデハ全ク下罰骨體外 ニ認メラル、ノミデ既二骨體內ニ於テハソ， 片型ヨモ認メラレナ1。

\section{V. 總 括}

（1）化骨 1 ケ月ノ胎兒二於ケル下顎骨ハ單ニ一ツノ纖維樣塊ニシテ中ニタ・゙メッ

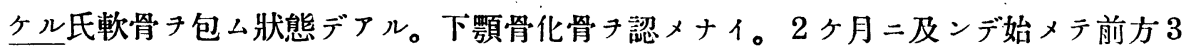

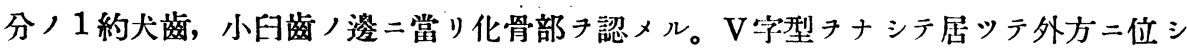
テ居ル。此ノV学型骨梁八(横斷面二於テ)上方哆開シソノ上ヨリ齒帶ノ侵入七ルチ認 
メル。後方 3 分, 2 八化管七ズ胎生 3 ケ月二至り前月後牛二於テ發有シタ頋溝ハ 3 万 月末二及ビ既二孔狀き呈シテ來ル，佾中 3 分， 1 站二後 3 分， 1 共二化骨現象明ラカ トナル特二後者八後來顆狀突起二ナル可キ處ト隅角二相當スル場所ノ所二於テ著明ナ

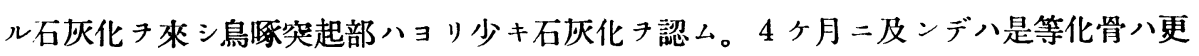

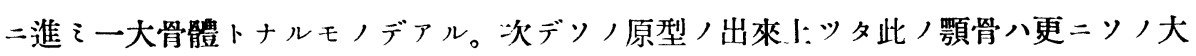
サト幅, 長サ二於テ發育スルモノデアル。

(2) 齒槽突起 齒槽突起ハ 3 ケ月終リニソノ形テ現シ4 ケ月二及ンデ明ラカ二各乳 齒數二一致七ル齒槽トソノ齒槽底部ヨリ分布七ル血管像認メル事得ル。

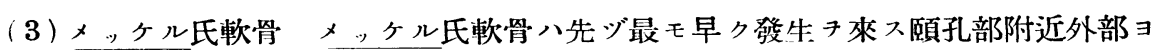
リ浸蝕サレ 6 ケ月二及ンデハ遂二買骨體內二認メザルニ至ル。

(4)正中聯接正中部，連接ハ結締織纖維性デアル(胎性期中)。

(5) 齒芽 齒芽, 發育八本論二於テハ直接關係ナキチ以テ之チ省ク。

余ハ本實驗二於テ主トシテ Schultze 或ハ Gantz 八樣ニ又囟透明法ニ依ツテソ， 化㓊點キ探究シタモノデァルガ, 而シ同氏等ノ樣 $=3 \%$, Potassium Hydroxid 或 八 Cedar oil キ用ヒズニ單ニ「アルコール」ノ上昇法キ用ヒテ後「キシロール」二依ツテ 透明鏡索セル處二異ナレル點アリ余ノ方法八非常二簡易デアル。

\begin{tabular}{|l|c|c|l|}
\hline 骨透明法 & & & \\
\hline Schultze & Alkohol Aufsteigend & $3 \%$ Potassium Hydroxid & Cedar oil \\
\hline Gantz & " & $5 \%$ & Cedar oil \\
\hline 可 兒 & " & & Xylol \\
\hline
\end{tabular}

今其, 成績キ考察シテ見ルニ下顎骨ノ化骨ハ(片顎)次ノ表二示ス樣二各著者二低リ テ甚ダ起始部二對シテノ數ガ一致キ缺イテ居ル。

Hamphry, Heitzman, Fawcett, Euler 等ハ1 ケ所き擧ゲ Gray ハ 5 ケ所キSutton ハ6 ケ所以上キ列擧シテ居ル, 而モ Sutton 泣二Gray 八薄膜緎維樣結締織ノ 3 乃至 4 ケ所テソノ起始點トシテ補助軟骨各 32 ケ所チソノ中ノ外二附加シテ居ル。郎チソ ，化骨點ハ 5 乃至 6 キ算スルモノデァル。余ノ場合二於テハ Sutton二於テ示メサレ タルモノトソノ數二於テ全ク同一デアル。郎チ薄膜結締織中チ起始點トスルモノ4, 補助軟骨 2 チモト、スルモノデァル。Sutton トハ全ク同意見キ持ツモノデ Gray ト 異ナル處八正中メッケル氏軟骨外側ノ化骨點ノ有無デアル。

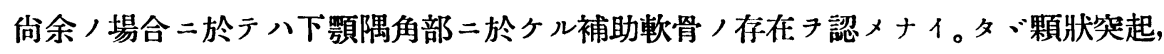
鳥四突起部二就テ認メタノミデアル。 


\begin{tabular}{|c|c|c|c|c|c|}
\hline \multirow[b]{3}{*}{ 人名 } & & 下 & 顝 & 骨 & 化 骨 （片＼cjkstart䫟） \\
\hline & & 始 部 & & \multirow[b]{2}{*}{ 化 } & \multirow[b]{2}{*}{ 基 始 部 化 骨 擴 張 狀 態 } \\
\hline & 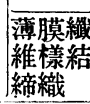 & 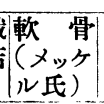 & 補助 & & \\
\hline Hamphry & 1 & & & 1 & メッケル氏軟骨前 3 分， 1 部外側化骨點 $リ$ 據張 \\
\hline Sutton & 4 & & 2 & 6 & 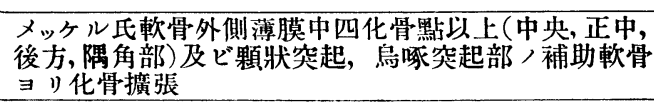 \\
\hline Heitzman & & 1 & & 1 & メックル氏軟骨中央部ョリ化骨擴張 \\
\hline Gray & 3 & & 2 & 5 & 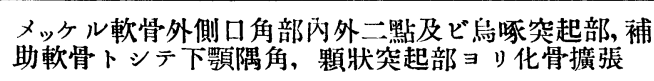 \\
\hline Fawcett & 1 & & & 1 & $\begin{array}{l}\text { メッケル氏軟骨外側頣孔部邊习基點二前方後方 }=\text { 化 } \\
\text { 骨攄張補助軟骨へモ化骨進展スル }\end{array}$ \\
\hline Euler & 1 & & & 1 & メッケル氏軟骨正中端外側 $ョ$ リ後方全部へ化骨擴張 \\
\hline 可 & 4 & & 2 & 6 & 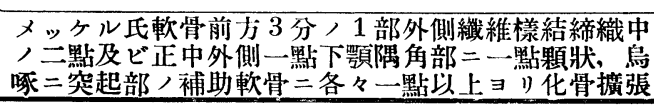 \\
\hline
\end{tabular}

\begin{tabular}{|c|c|c|}
\hline \multicolumn{3}{|c|}{ メッヶル氏軟骨，侵蝕 } \\
\hline 人 名 & 侵 蝕 起 點 & 消 失 時 期 \\
\hline Sutto & 正中終末部 & \\
\hline Gray & & 胎生 5,6 ヶ月 \\
\hline Fawcett & 中側切齒部 & \\
\hline Eulen & 正中終末部 & \\
\hline 可兒 & 犬 苜 部 & 胎生 6 ケ月 \\
\hline
\end{tabular}

メッケル氏軟骨ノ浸蝕起點八 (表示) 又 各著者二沿リ異ナルモノデァルガSutton 泣二 Euler 八正中終末部力ラ Fawcett ハ中側切齒部カラ始マルト記載 シテ居 ル。余ノ結果デ八願孔附近二於テ.先ジ最 初浸蝕サレルノ認メ夕。本軟感, 消失 時期ハGray／述ブルガ樣二胎生期 5 乃至 6 ケ月デアル。

\section{VI. 結 論}

余ハ胎生 1 ケ月カラ 10 ケ月迄ノ胎兒下顎ノ化骨起始點キ「キシロール」透明標本二 ヨリ檢索シ次ノ結果ヨ得タリ。

I 化骨八胎生 1 ケ月牛二始マル。

II 化骨起始點ハメッケル氏軟骨外側結締組織中二四ツ補助軟骨二ッァル。郎チ,

（イ）メッケル氏軟骨前方 3 分， 1 ，外側結締組織中 二 內外二點(後來齒槽，內外壁 子形成スルモノ)。

（ロ）正中部メッケル氏軟骨外側方。

（八）後方 3 分， 1 下顎隅角部。 
(二) 顆狀笑起部補助軟背。

(木)烏睆突起部補助質岗。

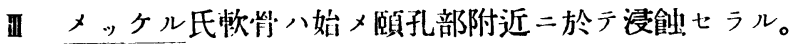

IV 胎兒 3 ケ月八終リ二於テ八乳齒二相當スル齒槽ノ存在于見ル。

V下顎骨兩牛部八正中線二於テ結締組織性連結キ有スルモノデアツテ分娩後始メ テソノ化骨キ見ルモノデアル。

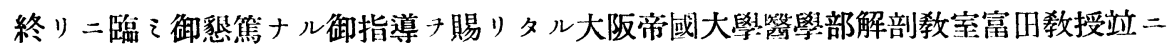

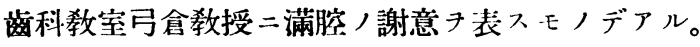

\section{文斯}

1) Sutton J. B. Die Entwicklung des Unter Kiefers. J. of the Br. D. Aas. 1883(V.B.)Ref. D. M. f. Z. 1883. H. 7 p. Korr f. Z. 1883. p. 339). 2) Röse, C., “ Über Die Entwicklung der Zähne des Menschen” (Arch. f. mikr. Anat. Bd. 38. 1891). 3) Toldt, C., “Über des Wachsthum des Unterkiefers.”(Zeitschr. f. Heilk. Bd. V. 1884). 4) Toldt, C., “Anatomischer Attas für stadierende med Arzte" (Bd. 1. p. 86. Figs 192-197, 6 Aufl, Berlin 1908). 5) Heitzman, Die frïheste Entwicklung des Unterkieferknochens. (Cosmos N. 8. p. 661. 1895. Ref. Oe. U. V. f. Z. H. I. p. 99. 1896. D. M. f. Z. H. 6. p. 254. 1896). 6) Herpin Dr. A., Die Entwicklung des Unter Kiefer. (D. z. Z. N. 52. p. 803-805. 1911). 7) Witzelkarl, “Entwicklung der Kiefer und der Zähne beim Menschen ”. (Berlin 1917).

8) Walkhoff, Der Menschliche Unterkiefer im Licht der Entwicklungs Mechanick(D. M. f. Z. H. 12. p. 529. 1920). 9) Gantz, I. Z, Fetal Development of the Human Jaws and teeth (Dental Cosmos. p. 131. Feb. 1922). 10) Fawcett, The developement of the Human Mandible (B. D. J. June. II. p. 669. 1924). 11) 青木貞亮, 商牙發育機轉ノレントゲン線 解剖學的研究. (日本苜科學會誌. 23 卷. 10. 11. 12).

\section{附 團 說 明}

第 1 圆 胎生 2 ケ月ラ 5 ケ月迄入胎兒下顎骨ノ「キシロール」透明標本, 化骨擴張ノ度 $コ$ 示ス (透過光線寫盚)。

第 2 圖 メッケル氏軟骨前方 3 分， 1 部邊二於ヶル橫断面(胎生 3 ケ月), 內外二化骨板が底部

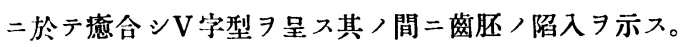

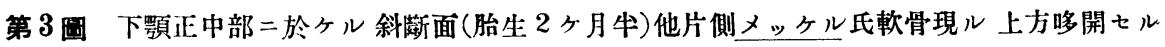
下顠化骨习示ス。

第 4 圖 胎生 2 ケ月末二於ヶル螠板模型，メッケル氏軟骨卜下靧化骨，狀態ヨ示ス。

第 5 圖前者 7 內側(舌側) $\exists$ リ示ス。

第 6 圖 後方化骨二起始點 7 示入(胎生 3 ケ月末)。

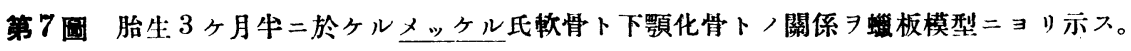

第 8 圖 胎生 4 ケ月後二於ヶル狀態。

第 9 圖 胎生 6 ケ月カラ 10 ケ月迄ノ「キシロール」透明標本(透過光線寫眞)。

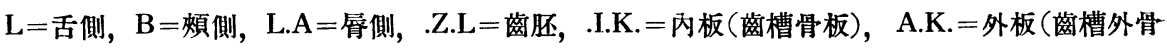

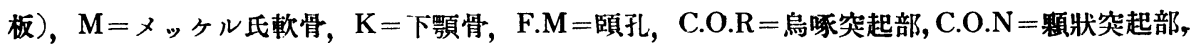
$\mathbf{K} . \mathbf{W}=$ 下顎隅角部。 
可兒論文附圖 I (Dr. I. Kani)

第 1 圖

第 6 圖
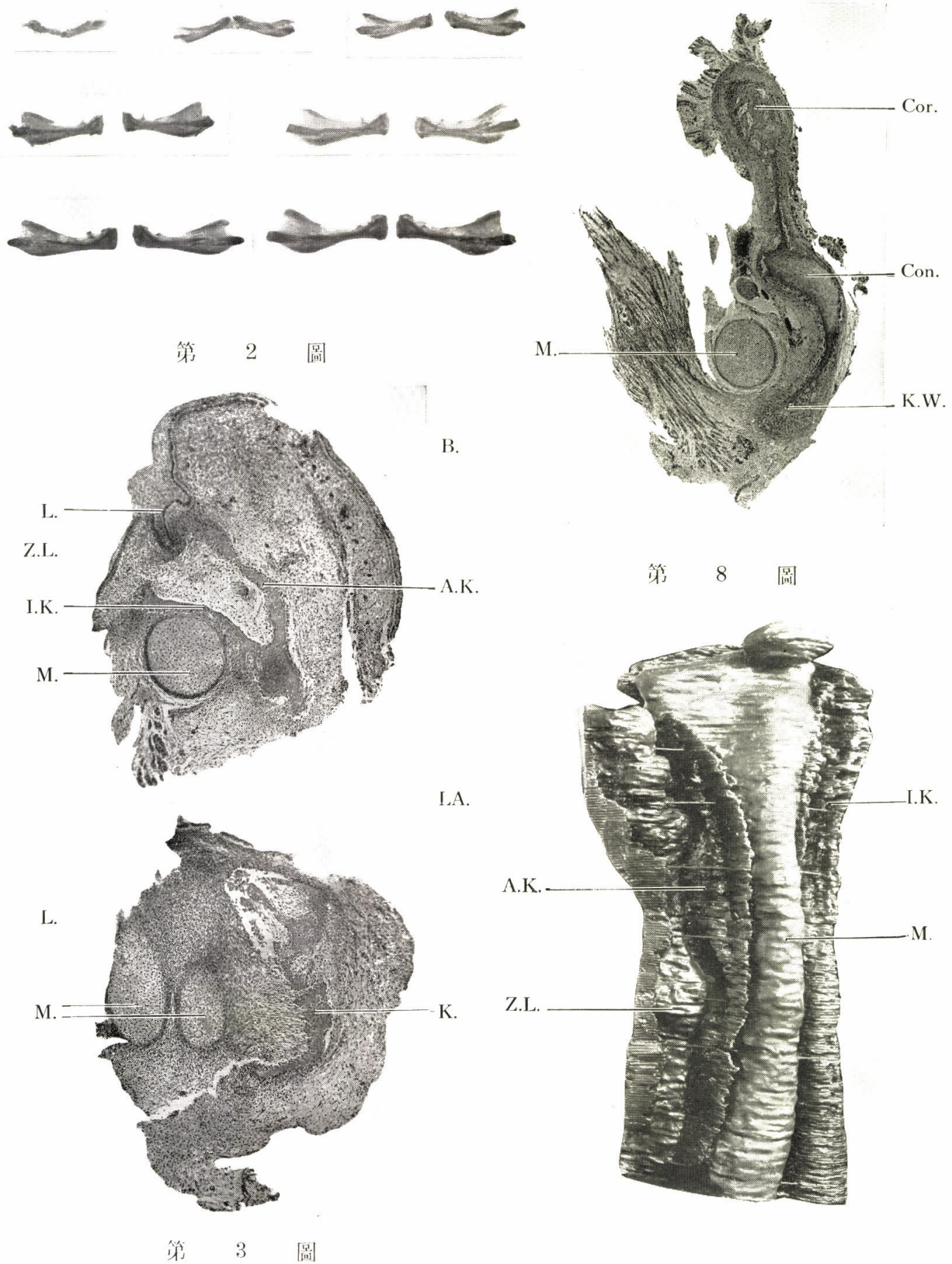
可兒論文附 圖 II (Dr. I. Kani)

第 7 㨽

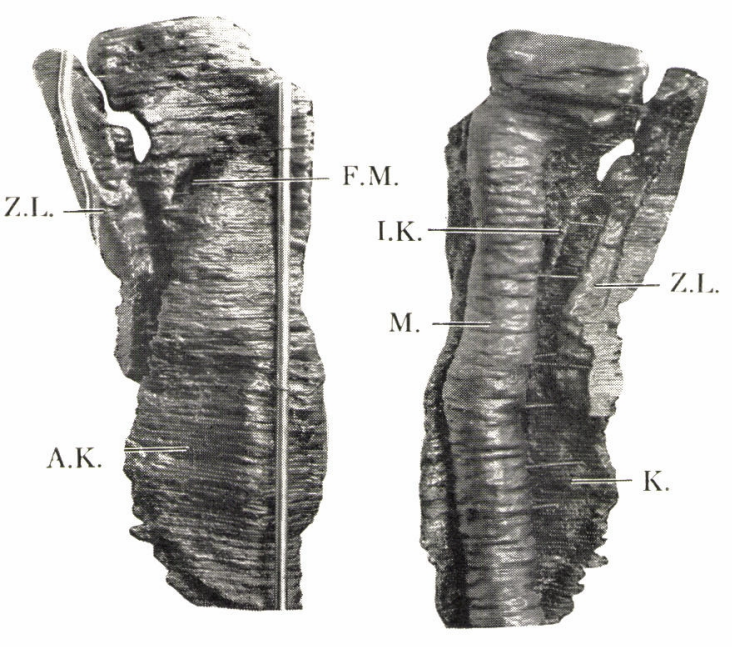

第 9 滴

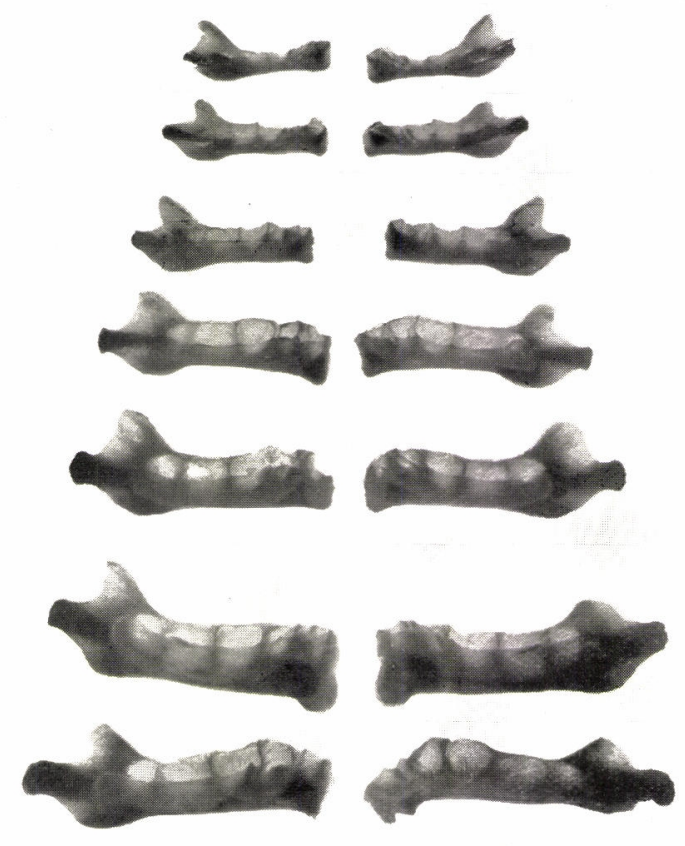

㘣|
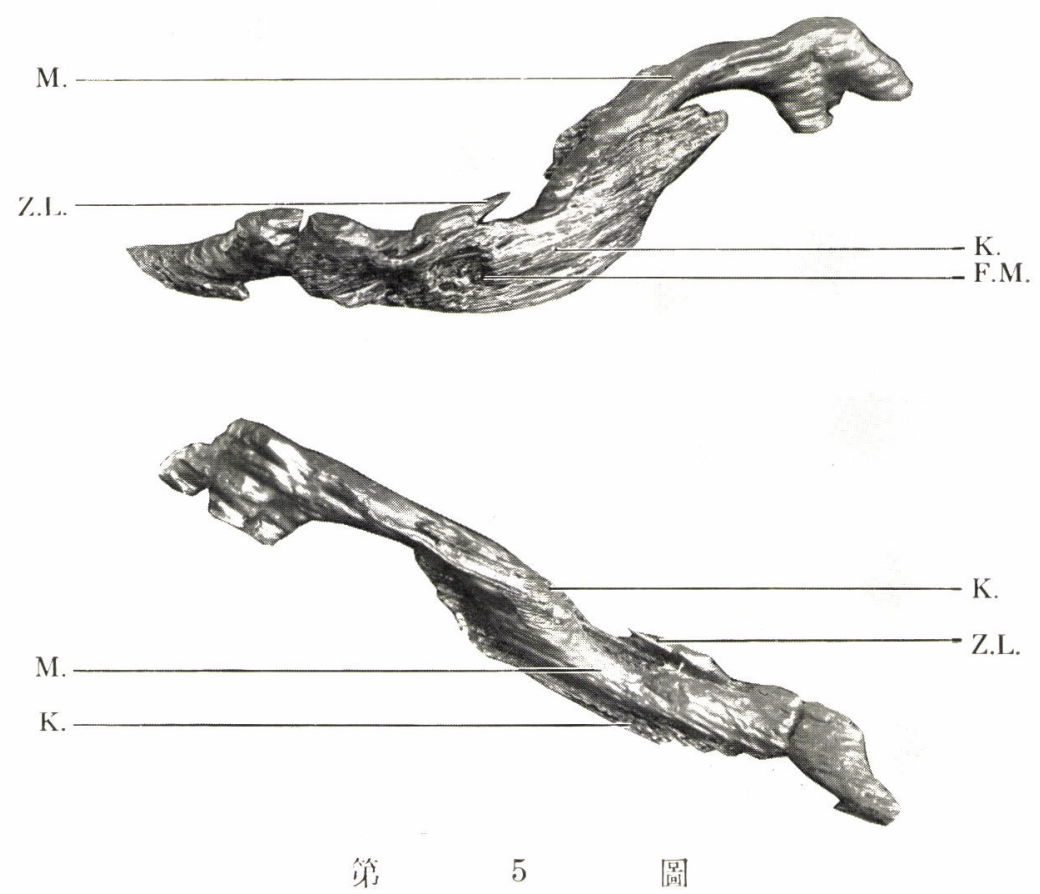